\title{
Energy and economic effectiveness of gas and gas-steam combined heat and power units fired with natural gas
}

ABSTRACT: The paper presents an analysis of energy and economic effectiveness of the combined heat and power (cogeneration) technologies fired with natural gas that may be deemed prospective for the Polish electric power system. The current state of the cogeneration technologies fired with natural gas in Poland is presented. Five cogeneration technologies fired with natural gas, prospective from the point of view of the Polish electric power system, were selected for the analysis. Namely, the paper discusses: gas-steam combined heat and power (CHP) unit with 3-pressure heat recovery generator (HRSG) and steam interstage reheat, gas-steam CHP unit with 2-pressure HRSG, gas-steam CHP unit with 1-pressure HRSG, gas CHP unit with small scale gas turbine, operating in a simple cycle and gas CHP unit with gas engine. The following quantities characterizing the energy effectiveness of the cogeneration technologies were selected for the analysis: electricity generation efficiency, heat generation efficiency, primary energy savings (PES) and $\mathrm{CO}_{2}$ unit emission. The economic effectiveness of particular technologies was

$\triangle$ Corresponding Author: Bolesław Zaporowski; e-mail: boleslaw.zaporowski@put.poznan.pl

1 Poznań University of Technology, Institute of Electric Power Engineering, Poznań, Poland; ORCID iD: 00000002-8330-3650; e-mail: boleslaw.zaporowski@put.poznan.pl

2019. The Author(s). This is an open-access article distributed under the terms of the Creative Commons Attribution-ShareAlike International License (CC BY-SA 4.0, http://creativecommons.org/licenses/by-sa/4.0/), which permits use, distribution, and reproduction in any medium, provided that the Article is properly cited. 
determined based on unit electricity generation costs, discounted for 2019, including the costs of purchasing $\mathrm{CO}_{2}$ emission allowances. The results of calculations and analyses are presented in a table and on a figures.

KEYWORDS: natural gas, cogeneration technologies, energy effectiveness, economic effectiveness

\section{Introduction}

Due to the Paris Agreement signed within the United Nations Framework Convention on Climate Change (UNFCCC) in Paris (12/12/2015) and the decision of the European Council of October 2014 on the $\mathrm{CO}_{2}$ emission reductions in the EU member states, the Polish electricity sector has been facing a great challenge of introducing, in the $1^{\text {st }}$ half of the $21^{\text {st }}$ century, electricity generation technologies that will lead to the significant reduction of $\mathrm{CO}_{2}$ emission.

In the upcoming years, the reduction of $\mathrm{CO}_{2}$ emissions in Poland may be achieved by means such as increasing the efficiency of coal-fired power plants, increasing the share of the natural gas and renewable energy sources, including wind, sun and biomass, in electricity generation, as well as increasing the share of combined heat and power (CHP) generation in the total electricity generation, including generation at gas-fired CHP plants. In longer terms, the mentioned reduction can also be achieved by introducing nuclear power plants. Combined heat and power generation is one of the effective methods of generating primary energy savings, which translate into reduced $\mathrm{CO}_{2}$ emissions and a reduction of costs of power and heat generation.

Currently and for the upcoming minimum of 30 years, natural gas may be deemed the best fuel for CHP plants, due to its ecological and technological advantages. The overall efficiency of converting natural gas chemical energy to electricity and heat reaches $85 \%$ in cogeneration units. In consequence, the unit $\mathrm{CO}_{2}$ emission can be reduced to circa $0.280 \mathrm{~kg} \mathrm{CO}_{2} / \mathrm{kWh}$.

\section{The current condition of Polish CHP generation using natural gas}

There is a paucity of CHP generation sources fired with natural gas in Poland. They include solely cogeneration units whose joint nominal electrical capacity equals circa 2,436.5 MW (Statistical Information... 2018). 11 gas-steam CHP units fired with natural gas (Gorzów Wielkopolski, Nowa Sarzyna, Lublin, Rzeszów, Zielona Góra, Siedlce, Polkowice, Głogów, Gorzów Wlkp. II, Włocławek and Płock) were launched within the National Power System (NPS) between 1999 and 2018, and constitute a certain novelty in the Polish energy sector. The gas tur- 
bines used in these units have been produced by the companies internationally pioneering in gas turbine production, such as: General Electric, Siemens, Ansaldo by Siemens, Solar Turbines and ABB. All the gas-steam units have been equipped with cogeneration, steam, extraction-condensing turbines, excluding the first gas-steam unit in the Gorzów Wielkopolski plant, where the gas turbine co-operates with two heat backpressure turbines (Statistics... 2018).

Interestingly, there are also 13 gas CHP plants with simple cycle gas turbines, including 18 gas turbines of unit nominal electrical capacities between 1.4 and $53 \mathrm{MW}$. The majority of them work in district heating systems, whereas two of them operate for industrial heating systems. Their overall nominal electrical capacity is equal to $204.9 \mathrm{MW}$.

Gas heat units with gas engines constitute an important group of CHP generation sources fired with natural gas. Out of these, cogeneration heat units with Rolls Royce gas engines have the highest unit nominal electrical capacity of 7.5 MW. They operate in heating systems in Wejherowo, Rzeszów and Leszno. There are currently about 80 CHP units with gas engines fired with natural gas, with the overall electrical capacity exceeding $170 \mathrm{MW}$. In addition, Poland has 38 gas CHP units with gas engines fired with gas from mine methane removal, of overall electrical capacity amounting to circa $88 \mathrm{MW}$, as well as 310 gas units with gas engines, of overall electrical capacity reaching circa $248 \mathrm{MW}$, fired with biogas coming from agricultural biogas plants, sewage treatment plants and municipal waste landfills (Statistics... 2018).

\section{Prospective gas and gas-steam CHP technologies using natural gas}

Cogeneration units operate both in the National Power System (NPS) as the sources of electricity and in the heat power systems, of different capacities, as sources of heat. The heat in cogeneration capacities should be adjusted to the demand for heat in heating systems. In turn, the electric power capacities should stem from the heat in cogeneration capacities. For this reason, this paper discusses prospective technologies that could be used in CHP units fired with natural gas, of the heat in cogeneration capacity ranging between several dozen $\mathrm{kW}$ and several hundred $\mathrm{MW}$.

Therefore, the following large- and medium-scale CHP units, fired with natural gas, have been selected for the energy and economic efficiency analysis (Zaporowski 2016):

$\checkmark$ gas-steam CHP unit with a 3-pressure heat recovery steam generator (HRSG) and interstage steam reheat, whose nominal electrical capacity ranges between 300 to $600 \mathrm{MW}$ and heat in cogeneration capacity is from 180 up to $350 \mathrm{MW}$ (see Fig. 1),

$\checkmark$ gas-steam CHP unit with a 2-pressure HRSG, whose nominal electrical capacity ranges between 80 to $300 \mathrm{MW}$ and heat in cogeneration capacity is from 70 up to $180 \mathrm{MW}$ (see Fig. 2),

$\checkmark$ gas-steam CHP unit with a 1-pressure HRSG, whose nominal electrical capacity ranges between 25 to $80 \mathrm{MW}$ and heat in cogeneration capacity is from 20 up to $70 \mathrm{MW}$ (see Fig. 3). 
In addition, the following small-scale CHP units (CHP distributed sources), fired with natural gas, have been selected for the energy and economic efficiency analysis (Zaporowski 2016):

$\checkmark$ gas CHP unit with a simple cycle gas turbine, whose nominal electrical capacity ranges between 1 and $15 \mathrm{MW}$ and heat in cogeneration capacity is from 1.5 up to $20 \mathrm{MW}$ (see Fig. 4),

$\checkmark$ gas CHP unit with a gas engine, whose nominal electrical capacity ranges between $150 \mathrm{~kW}$ and $7.5 \mathrm{MW}$ and heat in cogeneration capacity is from $150 \mathrm{~kW}$ up to $6.5 \mathrm{MW}$ (see Fig. 5).

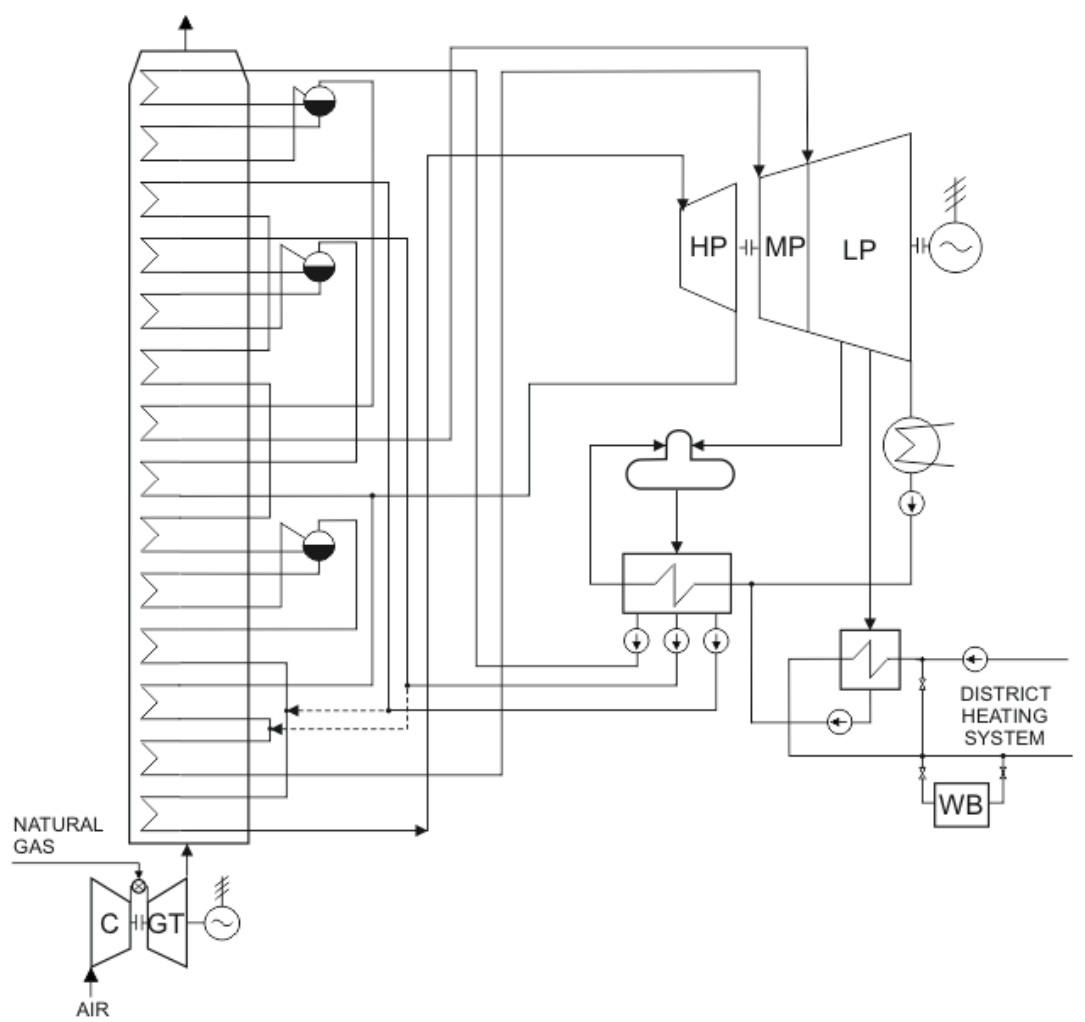

Fig. 1. Scheme of the technological system of a gas-steam CHP unit with a 3-pressure heat recovery steam generator and interstage steam reheat, fired with natural gas

Rys. 1. Schemat układu technologicznego ciepłowniczego bloku gazowo-parowego z 3-ciśnieniowym kotłem odzysknicowym i międzystopniowym przegrzewaniem pary, opalanego gazem ziemnym 


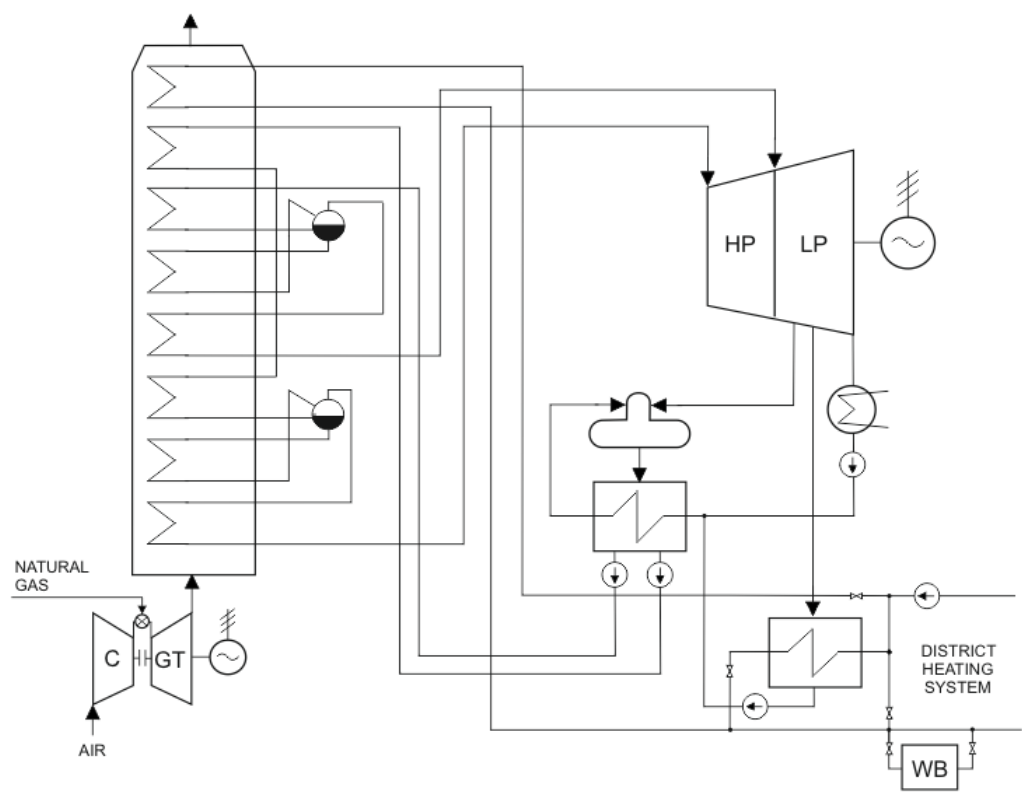

Fig. 2. Scheme of the technological system of a gas-steam CHP unit with a 2-pressure heat recovery steam generator, fired with natural gas

Rys. 2. Schemat układu technologicznego ciepłowniczego bloku gazowo-parowego z 2-ciśnieniowym kotłem odzysknicowym, opalanego gazem ziemnym

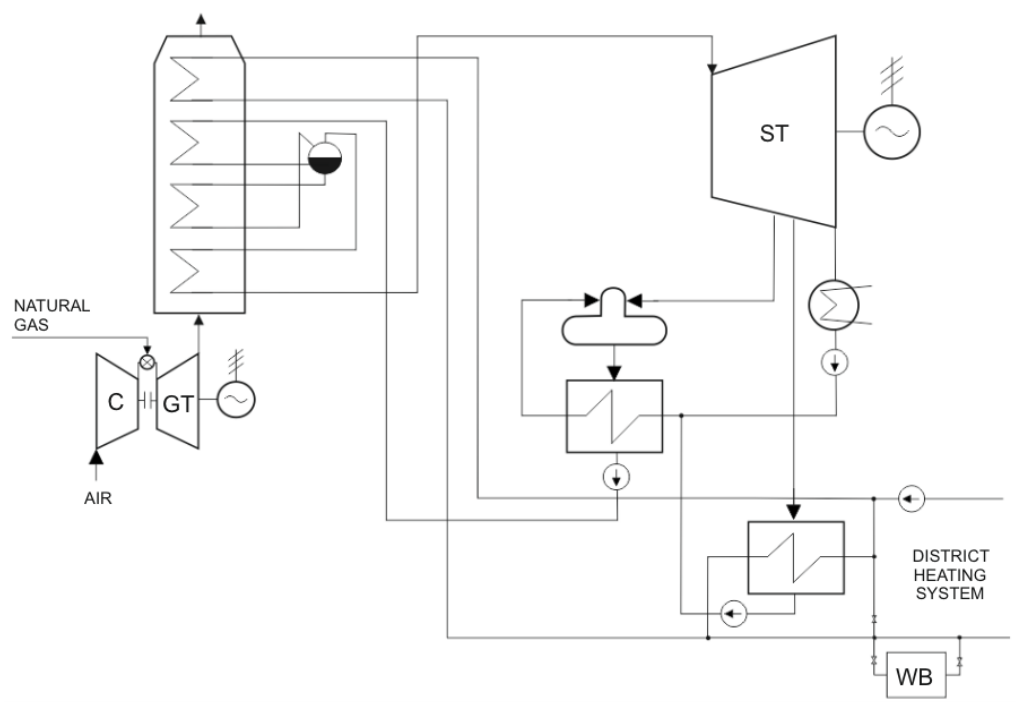

Fig. 3. Scheme of the technological system of a gas-steam CHP unit with a 1-pressure heat recovery, fired with natural gas

Rys. 3. Schemat układu technologicznego ciepłowniczego bloku gazowo-parowego z 1-ciśnieniowym kotłem odzysknicowym, opalanego gazem ziemnym 


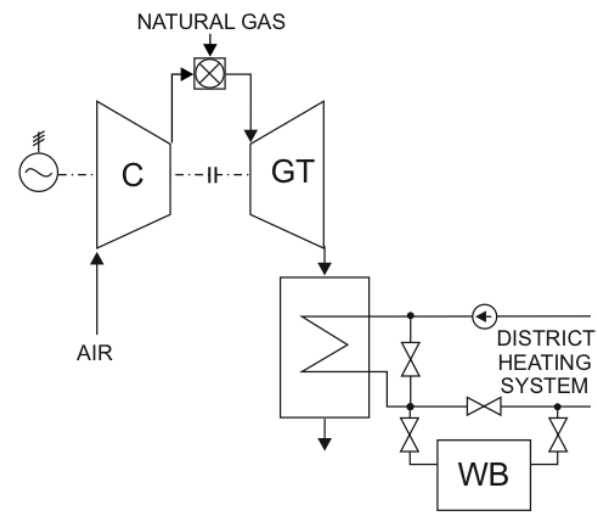

Fig. 4. Scheme of the technological system of a gas CHP unit with an simple cycle gas turbine, fired with natural gas

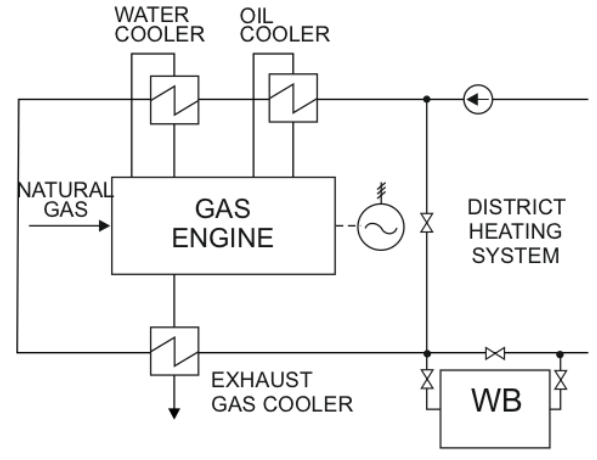

Fig. 5. Scheme of the technological system of a gas CHP unit with gas engine, fired with natural gas

Rys. 4. Schemat układu technologicznego ciepłowniczego Rys. 5. Schemat układu technologicznego ciepłowniczego bloku gazowego z turbiną gazową pracującą w obiegu bloku gazowego z silnikiem gazowym, opalanego gazem prostym, opalanego gazem ziemnym ziemnym

\section{Energy effectiveness and emission of CHP units fired with natural gas}

Three markers of energy generation effectiveness, namely: the efficiency of electricity production in cogeneration, the efficiency of heat production in cogeneration, and Primary Energy Savings (PAS), were determined for selected prospective CHP units (technologies), for large-, medium- and small-scale CHP plants fired with natural gas (Directive... 2012). Unit $\mathrm{CO}_{2}$ emission was also calculated for these technologies $\left(\mathrm{kg} \mathrm{CO}_{2} / \mathrm{kWh}\right)$. The results of calculations are presented in Table 1.

\section{Economic effectiveness of CHP units fired with natural gas}

The investment perspectives of selected CHP technologies discussed in Chapter 2 depend largely on their economic values. Unit electricity generation costs, discounted for 2019, were taken as markers of the technologies' economic effectiveness. They allow for a comparison of different cogeneration technologies used in large-, medium- and small-scale CHP plants. At the same time, the idea behind the analysis of economic effectiveness was that it should be a comparative 
TABLE 1. Quantities characterizing the energy effectiveness and emission of large-, mediumand small-scale CHP units fired with natural gas

TABELA 1. Wielkości charakteryzujące efektywność energetyczną i emisyjność bloków ciepłowniczych dużej, średniej i małej mocy, opalanych gazem ziemnym

\begin{tabular}{|c|l|c|c|c|c|}
\hline No. & \multicolumn{1}{|c|}{ Type of CHP unit } & $\begin{array}{c}\text { Electricity } \\
\text { generation } \\
\text { efficiency } \\
{[\%]}\end{array}$ & $\begin{array}{c}\text { Heat } \\
\text { generation } \\
\text { efficiency } \\
{[\%]}\end{array}$ & $\begin{array}{c}\text { Primary } \\
\text { Energy } \\
\text { Savings } \\
{[\%]}\end{array}$ & $\begin{array}{c}\mathrm{Un}^{\mathrm{U}} \mathbf{\mathrm { CO }} \mathrm{CO}_{2} \\
\text { emission } \\
{\left[\mathrm{kg} \mathrm{CO}_{2} / \mathrm{kWh}\right]}\end{array}$ \\
\hline 1 & $\begin{array}{l}\text { Gas-steam CHP unit with 3-pressure HRSG } \\
\text { and interstage steam reheat }\end{array}$ & 55.61 & 25.98 & 17.72 & 0.267 \\
\hline 2 & Gas-steam CHP unit with 2-pressure HRSG & 48.56 & 32.52 & 14.58 & 0.277 \\
\hline 3 & Gas-steam CHP unit with 1-pressure HRSG & 43.80 & 36.25 & 11.72 & 0.286 \\
\hline 4 & Gas CHP unit with simple cycle gas turbine & 32.01 & 53.80 & 11.60 & 0.286 \\
\hline 5 & Gas CHP unit with gas engine & 42.50 & 40.50 & 13.67 & 0.280 \\
\hline
\end{tabular}

one, of 5 selected technologies. The calculations of unit electricity generation costs, discounted for 2019, were made based on energy effectiveness and unit $\mathrm{CO}_{2}$ emission of particular technologies listed in Chapter 2 (Table 1) and on:

$\checkmark$ gas-steam, natural-gas-fired CHP plant construction time being 2 years in contrast to 1 year for distributed cogeneration sources,

$\downarrow$ heat sales price equal to 39.7 PLN/GJ,

$\checkmark$ discount rate being $7.5 \%$ for large- and medium-scale gas-steam CHP plants and 7\% for small-scale CHP plants (distributed sources).

The following items were taken into account when calculating the levelized costs of electricity: capital cost, fuel cost, maintenance cost, operation cost and environmental cost (costs of $\mathrm{CO}_{2}$ production allowances, i.e. the European Emission Allowances, EUA). EUA values were set in the amount of $126 \mathrm{PLN} / \mathrm{Mg} \mathrm{CO}_{2}\left(30\right.$ Euro/ $\mathrm{Mg} \mathrm{CO}_{2}$ ). The unit electricity generation costs were calculated in two variants, namely: 1) for cogeneration units operating in district heating systems, i.e. for the nominal electrical capacity utilization time: $\mathrm{T}_{\mathrm{e}}=5,200 \mathrm{~h} / \mathrm{year}$ and for CHP heat cycle time: $\mathrm{T}_{\mathrm{c}}=4,400 \mathrm{~h} / \mathrm{year}$, for gas-steam heat units, as well as for the nominal electrical and heat in cogeneration capacity utilization time $T_{e}=T_{c}=4,400 \mathrm{~h} /$ year, for gas units with gas engines and simple cycle gas turbines; 2) for cogeneration units operating in industrial heating systems or functioning as water heating sources, for $\mathrm{T}_{\mathrm{e}}=\mathrm{T}_{\mathrm{c}}=7,200 \mathrm{~h} /$ year, for all the cogeneration units analyzed. The calculation results are presented in Figure 6: 


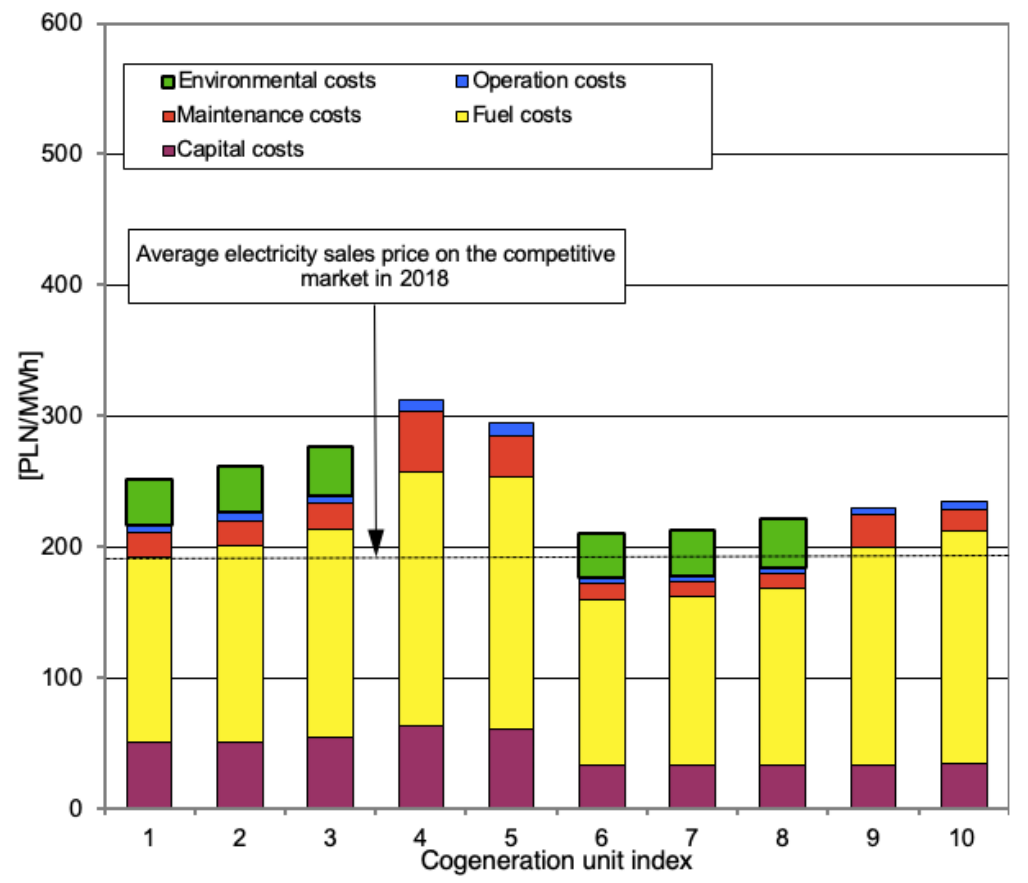

Fig. 6. Unit electricity generation costs, discounted for 2019, in large-, medium- and small-scale CHP plants, fired with natural gas [PLN/MWh], for: 1) gas-steam CHP unit with 3-pressure heat recovery steam generator (HRSG) and interstage steam reheat, for $\mathrm{T}_{\mathrm{e}}=5,200 \mathrm{~h} / \mathrm{y}$ and $\mathrm{T}_{\mathrm{c}}=4,400 \mathrm{~h} / \mathrm{y}, 2$ ) gas-steam CHP unit with 2-pressure HRSG, or $\mathrm{T}_{\mathrm{e}}=5,200 \mathrm{~h} / \mathrm{y}$ and $\mathrm{T}_{\mathrm{c}}=4,400 \mathrm{~h} / \mathrm{y}, 3$ ) gas-steam CHP unit with 1-pressure HRSG, for $\mathrm{T}_{\mathrm{e}}=5,200 \mathrm{~h} / \mathrm{y}$ and $\mathrm{T}_{\mathrm{c}}=4,400 \mathrm{~h} / \mathrm{y}, 4$ ) gas CHP unit with simple cycle gas turbine, for $\mathrm{T}_{\mathrm{e}}=\mathrm{T}_{\mathrm{c}}=4,400 \mathrm{~h} / \mathrm{y}, 5$ ) gas CHP unit with gas engine, for $\mathrm{T}_{\mathrm{e}}=\mathrm{T}_{\mathrm{c}}=4,400 \mathrm{~h} / \mathrm{y}, 6$ ) gas-steam CHP unit with 3-pressure HRSG and interstage steam reheat, for $\mathrm{T}_{\mathrm{e}}=\mathrm{T}_{\mathrm{c}}=7,200 \mathrm{~h} / \mathrm{y}, 7$ ) gas-steam CHP unit with 2-pressure HRSG, for $\mathrm{T}_{\mathrm{e}}=\mathrm{T}_{\mathrm{c}}=7,200 \mathrm{~h} / \mathrm{y}, 8$ ) gas-steam CHP unit with 1-pressure HRSG, for $\mathrm{T}_{\mathrm{e}}=\mathrm{T}_{\mathrm{c}}=7,200 \mathrm{~h} / \mathrm{y}, 9$ ) gas CHP unit with simple cycle gas turbine, for $T_{e}=T_{c}=7,200 \mathrm{~h} / y$ and 10) gas CHP unit with gas engine, for for $T_{e}=T_{c}=7200 \mathrm{~h} / \mathrm{y}$, with $\mathrm{CO}_{2}$ emission payment $126 \mathrm{PLN} / \mathrm{Mg} \mathrm{CO}_{2}\left(\mathrm{~T}_{\mathrm{e}}-\right.$ utilization time of nominal electrical capacity of cogeneration unit, $\mathrm{T}_{\mathrm{c}}-$ utilization time of cogeneration heat capacity of cogeneration unit)

Rys. 6. Jednostkowe, zdyskontowane na 2019 rok, koszty wytwarzania energii elektrycznej w elektrociepłowniach dużej, średniej i małej mocy, opalanych gazem ziemnym [zł/MWh] dla: 1) ciepłowniczego bloku gazowo-parowego z 3-ciśnieniowym kotłem odzysknicowym i międzystopniowym przegrzewaniem pary, dla $T_{e}=5200$ godz./rok $\mathrm{i} \mathrm{T}_{\mathrm{c}}=4400$ godz./rok, 2) ciepłowniczego bloku gazowo-parowego z 2-ciśnieniowym kotłem odzysknicowym, dla $\mathrm{T}_{\mathrm{e}}=5200$ godz./rok i $\mathrm{T}_{\mathrm{c}}=4400$ godz./rok, 3) ciepłowniczego bloku gazowo-parowego z 1-ciśnieniowym kotłem odzysknicowym, dla $\mathrm{T}_{\mathrm{e}}=5200$ godz./rok i $\mathrm{T}_{\mathrm{c}}=4400$ godz./rok, 4) ciepłowniczego bloku gazowego z silnikiem gazowym, dla $T_{e}=T_{c}=4400$ godz./rok, 5) ciepłowniczego bloku gazowego $\mathrm{z}$ turbiną gazową pracującą $\mathrm{w}$ obiegu prostym, dla $T_{e}=T_{c}=4400$ godz./rok, 6) ciepłowniczego bloku gazowo-parowego z 3-ciśnieniowym kotłem odzysknicowym i międzystopniowym przegrzewaniem pary, dla $T_{e}=T_{c}=7200$ godz./rok, 7) ciepłowniczego bloku gazowo-parowego z 2-ciśnieniowym kotłem odzysknicowym, dla $\mathrm{T}_{\mathrm{e}}=\mathrm{T}_{\mathrm{c}}=7200$ godz./rok, 8) ciepłowniczego bloku gazowo-parowego z 1-ciśnieniowym kotłem odzysknicowym, dla $\mathrm{T}_{\mathrm{e}}=\mathrm{T}_{\mathrm{c}}=7200$ godz./rok, 9) ciepłowniczego bloku gazowego $\mathrm{z}$ silnikiem gazowym, dla $\mathrm{T}_{\mathrm{e}}=\mathrm{T}_{\mathrm{c}}=7200$ godz./rok i 10) ciepłowniczego bloku gazowego $\mathrm{z}$ turbiną gazową pracującą w obiegu prostym, dla $\mathrm{Te}=\mathrm{Tc}=7200$ godz./rok, z uwzględnieniem opłaty za emisję $\mathrm{CO}_{2}$ w wysokości $126 \mathrm{zz} / \mathrm{Mg} \mathrm{CO}_{2}\left(\mathrm{~T}_{\mathrm{e}}-\right.$ czas wykorzystania elektrycznej mocy zainstalowanej jednostki kogeneracyjnej, $\mathrm{T}_{\mathrm{c}}-$ czas wykorzystania cieplnej mocy w skojarzeniu jednostki kogeneracyjnej) 


\section{Conclusions}

The commitments that Poland undertook pursuant the Paris Agreement of December 2015 and the decision of the European Council of October 2014 on the $\mathrm{CO}_{2}$ emission reduction in the EU member states by $40 \%$ by 2030 , in comparison to the 1990 levels, have created significant challenges for the Polish electric power sector. This refers also to combined power and heat production. Namely, the share of cogeneration in the overall heat production needs to be raised from the current level of $52.5 \%$ (Statistics... 2017) to circa $65 \%$ in 2035 and about $75 \%$ in 2050 (Zaporowski 2018) in order for Polish heating systems to be labelled as energy efficient (Notice.. 2019). By the same token, Polish power and heat production systems will be fuel- and technology-wise transformed into low-emission, cogeneration ones. This transformation refers mainly to coal-based cogeneration systems which would be changed into gas cogeneration systems. The system (network) heat is currently produced in coal- $(83 \%)$, gas- $(13 \%)$ and biomass-based (4\%) cogeneration in Poland (Statistics... 2018).

All modern cogeneration technologies should be characterized with high energy and economic effectiveness, as well as low $\mathrm{CO}_{2}$ emission. They should also be adjustable to varying heat and electricity loads especially when the plants are to supply district heating systems where the demand for heat changes in time. It would also be beneficial if the cogeneration heat and electricity sources exerted an effect on the NPS safety, i.e. if they met the criteria for Centrally Dispatched Generating Units (CDGU).

When it comes to large-scale CHP systems, gas-steam units with 3-pressure HRSG and interstage steam reheat, of heat in cogeneration capacity ranging between 180 and $350 \mathrm{MW}$ constitute a prospective cogeneration technology based on natural gas, characterized with high energy and economic effectiveness together with low $\mathrm{CO}_{2}$ emission. For these technologies used in district heating systems, the unit electricity generation costs, discounted for 2019, are equal to circa PLN 217/MWh while the costs of $\mathrm{CO}_{2}$ emission allowances amount to PLN 251/MWh. In turn, when they are used in industrial heating systems, their unit electricity generation costs, discounted for 2019, are equal to circa PLN 176/MWh while the costs of $\mathrm{CO}_{2}$ emission allowances amount to PLN 210/MWh. These CHP units can meet the criteria for CDGUs.

Among the medium-scale CHP systems, prospective cogeneration sources fired with natural gas and characterized with high energy and economic effectiveness boil down to the natural-gas -fired gas-steam units with 2-pressure HRSG, of heat in cogeneration capacity raging between 60 and $180 \mathrm{MW}$, for which the unit electricity generation costs, discounted for 2019, amount to PLN 226/MWh and the costs of $\mathrm{CO}_{2}$ emission allowances are PLN 178/MWh for district heating systems; at the same time the unit electricity generation costs, discounted for 2019 , amount to PLN 213/MWh for industrial heating systems. These CHP units can meet the criteria for CDGUs. In addition, cogeneration units of lower capacity, fired with natural gas, can be also installed in medium-scale heating systems, while these units are characterized with lower energy and economic effectiveness. They constitute gas-steam units with 1-pressure HRSG, 
whose heat in cogeneration capacity ranges between 20 and $60 \mathrm{MW}$. Their unit electricity generation costs, discounted for 2019, amount to PLN 239/MWh with the costs of $\mathrm{CO}_{2}$ emission allowances equal to circa PLN 276/MWh for district heating systems and PLN 184/MWh with the costs of $\mathrm{CO}_{2}$ emission allowances equal to circa PLN 221/MWh for industrial heating systems.

Finally, prospective technologies for small-scale heat generation systems fired with natural gas and characterized with high energy and economic effectiveness include gas CHP units (distributed cogeneration sources) with simple cycle gas turbines, of heat in cogeneration capacity ranging between 1 and $20 \mathrm{MW}$, and with gas engines of heat in cogeneration capacity ranging between $150 \mathrm{~kW}$ and $6.5 \mathrm{MW}$. These units are not obliged to purchase $\mathrm{CO}_{2}$ allowances provided they do not exceed their fuel nominal capacity (Notice... 2018). The unit electricity generation costs, discounted for 2019, amount to PLN 295-312/MWh for work with utilization time of nominal electrical capacity and heat in cogeneration capacity equal to $7,200 \mathrm{~h} /$ year.

An important problem affecting the energy and economic effectiveness of gas and gas-steam CHP plants lies in constant adjusting the heat capacity to the demand for heat in a heating system (district or industrial one), which should allow for these units to work in full cogeneration (with maximum heat in cogeneration capacity) for the longest time possible.

The energy and economic effectiveness of gas and gas-steam CHP units fired with natural gas is also determined by how long a plant can use its nominal electrical capacity and the capacity of heat in cogeneration. The problem of ensuring the plant's longest possible time of using the nominal electrical capacity and the capacity of heat in cogeneration arises frequently in district heating networks where the demand for heat changes in time. For this reason, heating systems need to be equipped with cogeneration units of different capacities and characteristics. It appears that this problem has been successfully solved in the Rzeszów heating system, where the following cogeneration units are installed: gas-steam unit of the nominal electrical capacity equal to $102 \mathrm{MW}$, including a gas turbine with the electrical capacity of $69 \mathrm{MW}$ and a steam extractioncondensing turbine with the electrical capacity of $32 \mathrm{MW}, 4$ gas units with gas engines whose nominal electrical capacity is equal to $7.5 \mathrm{MW}$ (each) and a steam unit with the electrical capacity of $9 \mathrm{MW}$ fired with municipal waste, which allows to adjust the heat in cogeneration capacities of the cogeneration units to the within-year changes in the demand for heat in the heating system. By the same token, these units can operate in the mode similar to full cogeneration, while the operating time of peak water boilers is minimized.

The analyzed gas and gas-steam cogeneration technologies, fired with natural gas, prospective for Polish electric power industry, have a number of advantages related to: energy effectiveness, economic effectiveness, unit $\mathrm{CO}_{2}$ emission and technological flexibility, in contrast to other cogeneration technologies, including the ones based on coal (Zaporowski 2017). 


\section{References}

Directive of the 2012/27/EU of the European Parliament and Council of 25 October

2012 on energy efficiency. Official Journal of the European Union, 2012, L315/1-315/56.

Statistical Information on Electricity (Informacja statystyczna o energii elektrycznej). 2018. No. 12. Agencja Rynku Energii S.A.

Notice of the Speaker of the Sejm of the Republic of Poland of $10^{\text {th }}$ May 2018 on publishing the uniform text of the Emission Trading Scheme, Journal of Laws 2018, item 1201 (Obwieszczenie Marszatka Sejmu Rzeczypospolitej Polskiej z dnia 10.05.2018 r. w sprawie ogtoszenia jednolitego tekstu ustawy o systemie handlu uprawnieniami do emisji gazów cieplarnianych. Dz.U. 2018, poz. 1201).

Notice of the Speaker of the Sejm of the Republic of Poland of $4^{\text {th }}$ May 2019 on publishing the uniform text of the Energy Act, Journal of Laws 2019, item 755 (Obwieszczenie Marszałka Sejmu Rzeczypospolitej Polskiej z dnia 04.05.2019 r. w sprawie ogloszenia jednolitego tekstu ustawy - Prawo energetyczne. Dz.U. 2019, poz. 755).

Statistics of the Polish Power Industry 2017 (Statystyka Elektroenergetyki Polskiej 2017). 2018. Agencja Rynku Energii S.A.

Statistics of the Polish Heat Industry 2016 (Statystyka Ciepłownictwa Polskiego 2016). 2017. Agencja Rynku Energii S.A.

ZAPOROWSKI, B. 2016. Energy Effectiveness and Economic Performance of Gas and Gas-Steam Combined Heat and Power Plants Fired with Natural Gas. Acta Energetica 1/26, pp. 152-157.

ZAPOROWSKI, B. 2017. Modern cogeneration technologies (Nowoczesne technologie skojarzonego wytwarzania energii elektryczneji ciepla). Polityka Energetyczna - Energy Policy Journal Vol. 20, Issue 3, pp. 41-53 (in Polish).

ZAPOROWSKI, B. 2018. Natural gas electricity generation development perspectives in Poland (Perspektywy rozwoju wytwarzania energii elektrycznej z gazu ziemnego w Polsce). Rynek Energii 5(138), pp. 3-8 (in Polish).

\section{Efektywność energetyczna i ekonomiczna kogeneracyjnych bloków gazowych oraz gazowo-parowych opalanych gazem ziemnym}

\section{Streszczenie}

W artykule przedstawiono aktualny stan kogeneracyjnych źródeł wytwórczych, opalanych gazem ziemnym w Polsce oraz analizę efektywności energetycznej i ekonomicznej tych źródeł. Zdefiniowano 5 perspektywicznych kogeneracyjnych technologii, opalanych gazem ziemnym, wybranych do analizy, a mianowicie: ciepłowniczy blok gazowo-parowy z 3-ciśnieniowym kotłem odzysknicowym i międzystopniowym 
przegrzewaniem pary, ciepłowniczy blok gazowo-parowy z 2-ciśnieniowym kotłem odzysknicowym, ciepłowniczy blok gazowo-parowy z 1-ciśnieniowym kotłem odzysknicowym, ciepłowniczy blok gazowy $\mathrm{z}$ turbiną gazową małej mocy pracującą w obiegu prostym oraz ciepłowniczy blok gazowy z silnikiem gazowym. Dla wybranych do analizy technologii kogeneracyjnych opalanych gazem ziemnym, wyznaczono wielkości charakteryzujące ich efektywność energetyczną, takie jak: sprawność wytwarzania energii elektrycznej w skojarzeniu, sprawność wytwarzania ciepła w skojarzeniu oraz oszczędność energii pierwotnej, a także jednostkową emisję $\mathrm{CO}_{2}$. Dla analizowanych technologii kogeneracyjnych opalanych gazem ziemnym wyznaczono również jednostkowe, zdyskontowane na 2019 rok, koszty wytwarzania energii elektrycznej, z uwzględnieniem kosztów uprawnień do emisji $\mathrm{CO}_{2}$, jako wielkości charakteryzujące ich efektywność ekonomiczną. Wyniki obliczeń i analiz przedstawiono w tabelach i na rysunkach. Artykuł jest zakończony wnioskami wskazującymi na zalety technologii kogeneracyjnych dla elektrociepłowni dużej, średniej i małej mocy opalanych gazem ziemnym.

SŁowA KLUCZOWE: gaz ziemny, technologie kogeneracyjne, efektywność energetyczna, efektywność ekonomiczna 